\title{
Un régimen penal juvenil verdaderamente humano y abierto a la esperanza
}

\author{
Padre Gustavo O. Carrara
}

Revista Derechos en Acción ISSN 2525-1678/ e-ISSN 2525-1686

Año 4/No 11 Otoño 2019 (21 marzo a 21 junio), 509-512

DOI: https://doi.org/10.24215/25251678e288

1. Buenas tardes, les agradezco la posibilidad de estar aquí, y el trabajo que se toman para escuchar con atención cada una de las intervenciones. Cuando hablamos y nos posicionamos acerca de un tema importante, en este caso sobre la posibilidad de un régimen penal juvenil, lo hacemos fuertemente influenciados por nuestras convicciones y por nuestras experiencias concretas de vida. No hay miradas neutras de la realidad, por eso quisiera intentar aportar una mirada humanista y cristiana, y a su vez apoyarme en la experiencia de vivir y trabajar pastoralmente hace 12 años en las villas de Buenos Aires.

2. Cuando visitamos a un adolescente en un instituto de menores, como adultos debemos reconocer, que en un punto, hemos llegado tarde. Que esto no debería haber ocurrido. Y haciendo memoria de nuestra niñez y adolescencia, nos preguntamos, ¿por qué ellos y yo no? En estos lugares nos encontramos mayoritariamente con adolescentes que desde el inicio de su vida han padecido la pobreza multidimensional. Qué duro es cuando el primer encuentro mano a mano del Estado con estos menores se da a través de la justicia penal. Por eso el tratamiento de esta ley no tiene que hacer olvidar el problema de fondo. ¿El problema son los menores pobres en conflicto con la ley o el problema profundo y de raíz es la decisión y voluntad de sostener a lo largo del tiempo una política de Estado de inclusión e integración social? 
3. Ahora bien, es verdad, Argentina no tiene un régimen de responsabilidad penal juvenil como lo dispone la Convención de los Derechos del Niño. Sería deseable que se abandonara el sistema tutelar y se implementara un régimen penal juvenil, con todas las garantías del proceso penal, pero sin bajar la edad mínima de responsabilidad penal juvenil, es decir, manteniéndola en 16 años, lo que sería más acorde a los estándares internacionales de derechos humanos y, en particular, con dicha Convención. En este marco aparecen caminos concretos que deben incluirse en dicho régimen penal juvenil: la justicia restaurativa, la mediación, la remisión de casos, las medidas no privativas de libertad. Es evidente que la implementación de este sistema depende de la habilitación de la infraestructura y los recursos humanos y materiales necesarios para el desarrollo de un sistema orientado a la resocialización y a la educación. Hay que trabajar por un régimen penal juvenil verdaderamente humano y abierto a la esperanza.

4. Los menores que son llevados al delito por organizaciones criminales son sus víctimas. El Estado debe alejarlos de esa opción en lugar de reafirmarlos en el rol de delincuente. Cuando vemos adolescentes que tienen armas en sus manos, lo primero que deberíamos preguntarnos es ¿por qué no les hemos acercado antes una propuesta positiva? ¿Por qué los hemos dejado en orfandad, expuestos a situaciones que los dañan a ellos en primer lugar? La pregunta no es tanto ¿qué le pasa a los adolescentes?, sino ¿qué nos pasa a los adultos? Por otro lado ciertamente los adolescentes no son responsables del tráfico de armas que se da en nuestra sociedad, muchas veces ligado al narcotráfico. Este contexto es particularmente dramático en villas y barrios precarios, cuya población está compuesta por casi la mitad de niños, niñas y adolescentes.

5. En estos lugares hay que tener particularmente presente el concepto amplio de inseguridad, eso que atenta contra la vida digna de los vecinos y vecinas. Por eso el camino comienza insertando a todos los chicos en las escuelas, y a sus familias en 
trabajos dignos, generando espacios públicos de esparcimiento y recreación, habilitando instancias de participación ciudadana, servicios sanitarios, acceso a los servicios básicos -agua, electricidad, cloacas-, por nombrar sólo algunas medidas. Ahí empieza todo proceso de integración socio-urbana.

6. Es necesario tener cuidado del populismo penal. No se trata aquí de la confianza en alguna función social tradicionalmente atribuida a la pena pública, sino más bien en la creencia de que mediante tal pena se pueden obtener los beneficios que requerirían la implementación de otro tipo de política social, económica y de inclusión social. Por otro lado hay que evitar esa tendencia que algunas veces existe de construir deliberadamente enemigos: figuras estereotipadas, que concentran en sí mismas todas las características que la sociedad percibe o interpreta como peligrosas. Los mecanismos de formación de estas imágenes son los mismos que, en su momento, permitieron la expansión de las ideas racistas ${ }^{1}$. Y todo esto se vuelve más delicado aún si estamos hablando de menores.

7. La respuesta a los inimputables es el cumplimiento de la Ley de Protección Integral de los Derechos de Niñas, Niños y Adolescentes (Ley No 26.061). "Los Estados deben abstenerse de castigar penalmente a los niños que aún no han completado su desarrollo hacia la madurez, y por tal motivo no pueden ser imputables. Ellos, en cambio, deben ser los destinatarios de todos los privilegios que el Estado puede ofrecer, tanto en lo que se refiere a políticas de inclusión como a prácticas orientadas a hacer crecer en ellos el respeto por la vida y por los derechos de los demás"2. La deuda social es la gran deuda de los argentinos, no se trata solamente de un problema económico o estadístico. Es principalmente un problema ético que nos afecta en nuestra dignidad más esencial. Detrás de las estadísticas

1 Cfr. Papa Francisco. Discurso a una delegación de la Asociación Internacional de Derecho Penal. 23/10/2014

2 Papa Francisco. Ibídem. 
—nunca hay que olvidarlo- hay rostros e historias. La deuda social genera graves daños sobre la vida concreta de personas, las hiere profundamente en su dignidad. Y casi la mitad de los niños, niñas y adolescentes de nuestra patria son pobres.

8. Por último me permito recordar que este honorable congreso votó por unanimidad la ley de integración socio-urbana. Esta Ley tuvo un trabajo de relevamiento previo de 4.228 barrios populares. Lo traigo a la memoria porque la mitad de los habitantes de estos barrios son niños, niñas y adolescentes. Hay que seguir llevando adelante este proceso de integración socio-urbana de las villas y barrios precarios de nuestro país. Es probable que esto no resuelva totalmente el drama de la pobreza en nuestra Patria, pero ciertamente será mirarlo de frente y poner manos a la obra de modo bien concreto.

Gustavo Oscar Carrara

Obispo Auxiliar de Buenos Aires

Vicario para la Pastoral de Villas de CABA Asesor de la Comisión Arquidiocesana de Niñez y Adolescencia en Riesgo del Arzobispado de Buenos Aires 